\title{
Electrophoresis of Soluble Proteins from Two Species of Xenorhabdus, Bacteria Mutualistically Associated with the Nematodes Steinernema spp. and Heterorhabditis spp.
}

\author{
By PHYLLIS G. HOTCHKIN ${ }^{1 *}+$ AND HARRY K. KAYA 2 \\ ${ }^{1}$ Department of Entomology and ' Division of Nematology, University of California, Davis, \\ CA 95616, USA
}

(Received 10 January 1984; revised 14 June 1984)

\begin{abstract}
Mutualistically associated bacteria were isolated from two genera of nematodes: Xenorhabdus nematophilus from four species of Steinernema (=Neoaplectana) and $X$. luminescens from two species of Heterorhabditis. Mutualistic bacteria were also isolated from two unidentified species of heterorhabditid nematodes and were partially characterized by selected standard bacteriological tests. The soluble proteins obtained from the primary and secondary forms of these bacteria were subjected to electrophoretic examination on acrylamide gels. Total protein profiles and certain isoenzyme electrophoregrams were compared. The results revealed distinct subspecific differences in profiles of $X$. nematophilus and suggested new subspecific groupings in $X$. luminescens.
\end{abstract}

\section{INTRODUCTION}

A symbiotic and specific association has been demonstrated between the bacterium Xenorhabdus nematophilus and species of the nematode Steinernema (=Neoaplectana), and between $X$. luminescens and Heterorhabditis spp. (Thomas \& Poinar, 1979; Akhurst, 1983b). Each bacterial species occurs in at least two forms (designated as primary and secondary) which can be distinguished as differently pigmented colonies on various bacteriological media (Akhurst, 1980).

All bacteria associated with species of Heterorhabditis have been identified as $X$. luminescens with no subspecific designation (Akhurst, 1983a); X. nematophilus associated with Steinernema spp. has been given three subspecific designations based on host specificity, pigmentation and biochemical tests (Akhurst, 1983a). These subspecific groupings are: group I, X. nematophilus subsp. nematophilus (associated with $S$. feltiae); group Il, $X$. nematophilus subsp. bovienii (associated with $S$. bibionis); and group III, $X$. nematophilus subsp. poinarii (associated with $S$. glaseri). Bacteria associated with $\boldsymbol{S}$. kraussei and unidentified Steinernema species are currently in a group designated IV.

Electrophoretic techniques allow rapid and accurate identification of organisms. They are especially useful in clarifying relationships at subspecific and population levels when examining individual genetic variants (Kersters \& De Ley, 1980). We examined the primary and secondary forms of Xenorhabdus spp. associated with described species of Steinernema and Heterorhabditis. In addition, we characterized associated bacteria from two undescribed isolates of Heterorhabditis by electrophoretic and standard bacteriological methods.

$\uparrow$ Present address: Dept of Microbiology, University of Medicine and Dentistry, PO Box 55, Piscataway, NJ 08854, USA.

\footnotetext{
Abbretiations: 6PG, 6-phosphogluconate dehydrogenase; G6P, glucose-6-phosphate dehydrogenase; LDH, lactate dehydrogenase: MDH, malate dehydrogenase; PGM, phosphoglucomutase; PMS, phenazine methosulphate.
} 


\section{METHODS}

Bacterial strains and growth conditions. Sources of bacteria and nematodes are listed in Table 1. Bacterial cultures were isolated from nematode colonies maintained in our laboratory as follows. Galleria mellonella larvae, infected with a single nematode strain, were dissected after 24,48 or $72 \mathrm{~h}$ and haemolymph containing bacterial cells was streaked on an agar plate (see below).

To prevent clonal selection, bacteria from many colonies were used to streak new plates. These isolates were cultured and maintained on NBT agar (nutrient agar with $25 \mathrm{mg}$ bromothymol blue $]^{-1}$ and $30 \mathrm{mg}$ 2,3,5-triphenyltetrazolium chloride $\mathrm{I}^{-1}$ ) in the dark at $24^{\circ} \mathrm{C}$. For electrophoresis, bacteria from single colony isolates and multiple colony isolates were cultured in nutrient broth on a shaker at room temperature $\left(25 \pm 2{ }^{\circ} \mathrm{C}\right)$ for $24 \mathrm{~h}$.

Colony morphology and pigmentation. Heterorhabditis spp. obtained from the Netherlands (Simons, 1981) and Victorville, Calif., USA (Bowen, 1982) had associated luminescent bacteria presumed to be $X$. Iuminescens (which are henceforth designated as isolates of $X$. (uminescens). Because these bacteria were uncharacterized, we did tests to obtain some basic information. The presumed primary and secondary forms were cultured, as described above. then observed for motility and stained for Gram reaction. Catalase activity was tested by flooding cultures with $10 \%(v / v)$ hydrogen peroxide. Three-day-old cultures were observed for bioluminescence, colony size and antibiotic activity (Akhurst, 1982) against strains of $X$. nematophilus. Pigmentation was also observed at 1 and $3 \mathrm{~d}$ on nutrient and MacConkey agar and at $3 \mathrm{~d}$ on NBT agar.

Preparation of soluble proteins. For electrophoresis, spheroplasts were prepared as follows. Bacterial cultures were centrifuged at $2500 \mathrm{~g}$ for $10 \mathrm{~min}$. The pellets were resuspended in $33 \mathrm{mM}-\mathrm{Tris} / \mathrm{HCl} \mathrm{pH} 7.5,50 \mathrm{mM}-\mathrm{NaCl}$ and recentrifuged. These pellets were resuspended in buffer ( $1 \mathrm{mM}$-EDTA, $10 \mathrm{mM}$-Tris/HCl $\mathrm{pH} \mathrm{7.5,} \mathrm{0.5} \mathrm{M-sucrose)}$ containing $50 \mu \mathrm{g}$ lysozyme $\mathrm{ml}^{-1}$ and $\mathrm{kept}$ at $25 \pm 2{ }^{\circ} \mathrm{C}$ for $30 \mathrm{~min}$. Lysozyme was removed from the spheroplasts by centrifuging ( $2500_{g}$ for $15 \mathrm{~min}$ ) twice in the buffer. Pellets of washed spheroplasts were resuspended in electrophoresis sample buffer [62.5 mM-Tris/ $/ \mathrm{HCl}$ pH 6.8, $10 \%$ (v/v) glycerol, $0.001 \%(\mathrm{w} / \mathrm{v})$ bromophenol blue] and sonicated using a Sonurgy Model G-15F (Fibra-Sonics Inc., Chicago, Ill., USA) on ice for $20 \mathrm{s.}$

Protein assay. The protein content of spheroplasts used for electrophoresis was determined by the method of Bradford (1976) using Coomassie Brilliant Blue G-250. Standard protein was prepared from a $24 \mathrm{~h}$ nutrient broth culture of the All primary strain of $X$. nematophilus. Cells were pelleted, resuspended in double distilled water and then passed three times through a French pressure cell press at $15000 \mathrm{lbf} \mathrm{in}^{-2}(103.5 \mathrm{MPa})$. Cell walls and membranes were removed by centrifugation at $15000 \mathrm{~g}$ for $30 \mathrm{~min}$. The supernatant was dialysed in three changes of double distilled water for $24 \mathrm{~h}$, lyophilized, and stored at $-70^{\circ} \mathrm{C}$. All procedures were done on ice or at $10^{\circ} \mathrm{C}$.

Electrophoretic techniques. Gels and buffers were used as described by Davis (1964). The pH of the separating gel was 8.9 for protein profiles and lactate dehydrogenase (LDH) and 7.3 for glucose-6-phosphate dehydrogenase (G6P) and malate dehydrogenase (MDH). Soluble proteins (300-400 $\mathrm{gg}$ samples) were loaded on $1 \cdot 25 \mathrm{~mm}$ thick. vertical slab gels (Model SE 500; Hoeffer Scientific Instruments, San Francisco, Calif., USA). Proteins were electrophoresed at $80 \mathrm{~V}$ through the $4 \%(w / v)$ acrylamide stacking gel and at $120 \mathrm{~V}$ through the $7 \%(w / v)$ acrylamide separating gel for about $5 \mathrm{~cm}$. Gels were cooled during electrophoresis to $17 \pm 1^{\circ} \mathrm{C}$ with water circulating through an internal chamber.

Protein profiles were visualized by staining gels with $0.1 \%(w / v)$ Coomassie Brilliant Blue in $50 \%$ methanol $/ 10 \%$ glacial acetic acid at $50{ }^{\circ} \mathrm{C}$ for $1 \mathrm{~h}$. Gels were destrained in $25 \%$ methanol $/ 10 \%$ glacial acetic acid and stored in this solution.

To detect isoenzymes, gels were incubated at room temperature with ( $\left.\mathrm{ml}^{-1}\right) 5 \mathrm{mg}$ of the appropriate substrate, $1 \mathrm{mg}$ coenzyme, $0.1 \mathrm{mg}$ phenazine methosulphate (PMS) and $1 \mathrm{mg}$ 3-(4,5-dimethylthiazolyl-2)-2,5-diphenyltetrazolium bromide (MTT) in $100 \mathrm{mM}$-Tris/HCl. The substrates for MDH and LDH were L-malic acid and DLlactic acid, respectively; the coenzyme used was $\beta$-nicotinamide adenine dinucleotide (NAD) in buffer at pH 7.0. The substrates for G6P and 6-phosphogluconate dehydrogenase (6PG) were D-glucose 6-phosphate and 6phosphogluconate, respectively; the coenzyme used was $\beta$-nicotinamide adenine dinucleotide phosphate (NADP) in buffer at pH 7.0. Phosphoglucomutase (PGM) was stained with $\alpha-\mathrm{D}-\mathrm{glucose}$ I-phosphate, 0.8 units G6P $\mathrm{ml}^{-1}$, $2 \mathrm{mg} \mathrm{MgCl}_{2} \mathrm{ml}^{-1}$, $0.5 \mathrm{mg}$ EDTA ml-1 in buffer at pH 7.0 with PMS, NADP and MTT as above. After visualization of isoenzymes, gels were stored in $25 \%$ methanol $/ 10 \%$ glacial acetic acid.

\section{RESULTS}

Results of the standard bacteriological tests on the Netherlands and Victorville isolates of $X$. luminescens are summarized in Table 2. Colonies of the Victorville isolate of $X$. luminescens on NBT agar were typical of those described for the other isolates in the species. The primary form was convex, circular with a slightly irregular margin, green with a red centre, and with a clear zone in the agar around the colony; the secondary form was flatter, with a wider circle, which had a more irregular margin, blue with a red centre, and with no clear zone in the agar. The primary form of the Netherlands isolate was similar to those previously described: convex, 
Table 1. Sources of isolates of Xenorhabdus

\begin{tabular}{|c|c|c|c|c|c|}
\hline Species or subspecies & Isolate & Form ${ }^{*}$ & Associated nematode & $\begin{array}{l}\text { Country } \\
\text { (state) }\end{array}$ & Sourcet \\
\hline $\begin{array}{l}X . \text { nematophilus } \\
\text { subsp. nematophilus }\end{array}$ & $\begin{array}{l}\text { All1 } \\
\text { All2 } \\
\text { A24 } \\
\text { A25 } \\
\text { Agro } \\
\text { Bret } \\
\text { Ital } \\
\text { Mexl } \\
\text { Mex2 }\end{array}$ & $\begin{array}{l}\mathbf{P} \\
\mathbf{S} \\
\mathbf{P} \\
\mathbf{S} \\
\mathbf{P} \\
\mathbf{P} \\
\mathbf{P} \\
\mathbf{P} \\
\mathbf{S}\end{array}$ & $\begin{array}{l}\text { Steinernema feltiae } \\
\text { S. feltiae } \\
\text { S. feltiae } \\
\text { S. feltiae } \\
\text { S. feltiae } \\
\text { S. feltiae } \\
\text { S. feltiae } \\
\text { S. feltiae } \\
\text { S. feltiae }\end{array}$ & $\begin{array}{l}\text { USA (Georgia) } \\
\text { USA (Georgia) } \\
\text { USSR } \\
\text { USSR } \\
\text { USSR } \\
\text { France } \\
\text { Italy } \\
\text { Mexico } \\
\text { Mexico }\end{array}$ & $\begin{array}{l}1 \\
1 \\
2 \\
2 \\
2 \\
3 \\
4 \\
5 \\
5\end{array}$ \\
\hline $\begin{array}{l}X \text {. nematophilus } \\
\text { subsp. botienii }\end{array}$ & $\begin{array}{l}\text { Bibl } \\
\text { Bib2 } \\
\text { T319/1 } \\
\text { T319/2 }\end{array}$ & $\begin{array}{l}\mathbf{P} \\
\mathbf{S} \\
\mathbf{P} \\
\mathbf{S}\end{array}$ & $\begin{array}{l}\text { S. bibionis } \\
\text { S. bibionis } \\
\text { S. bibionis } \\
\text { S. bibionis }\end{array}$ & $\begin{array}{l}\text { Australia } \\
\text { Australia } \\
\text { Australia } \\
\text { Australia }\end{array}$ & $\begin{array}{l}2 \\
2 \\
2 \\
2\end{array}$ \\
\hline $\begin{array}{l}X \text {. nematophilus } \\
\text { subsp. poinarii }\end{array}$ & $\begin{array}{l}\text { Glas } \\
\text { G6 }\end{array}$ & $\mathbf{S}$ & $\begin{array}{l}\text { S. glaseri } \\
\text { S. glaseri }\end{array}$ & $\begin{array}{l}\text { USA (N. Carolina) } \\
\text { USA (N. Carolina) }\end{array}$ & $\begin{array}{l}6 \\
2\end{array}$ \\
\hline Xenorhabdus sp. & $\begin{array}{l}\text { SK3/1 } \\
\text { SK3/2 } \\
\text { Q58/1 } \\
\text { Q58/2 }\end{array}$ & $\begin{array}{l}P \\
\mathbf{S} \\
\mathbf{P} \\
\mathbf{S}\end{array}$ & $\begin{array}{l}\text { S. kraussei } \\
\text { S. kraussei } \\
\text { Steinernema sp. } \\
\text { Steinernema sp. }\end{array}$ & $\begin{array}{l}\text { Czechoslovakia } \\
\text { Czechoslovakia } \\
\text { Australia } \\
\text { Australia }\end{array}$ & $\begin{array}{l}2 \\
2 \\
2 \\
2\end{array}$ \\
\hline$X$. Iuminescens & $\begin{array}{l}\text { B2 } \\
\mathrm{C} 1 \\
\mathrm{C} 2 \\
\mathrm{H} 1 \\
\mathrm{H} 2 \\
\mathrm{~N} 1 \\
\mathrm{~N} 2 \\
\mathrm{~V} 1 \\
\mathrm{~V} 2\end{array}$ & $\begin{array}{l}\mathbf{S} \\
\mathbf{P} \\
\mathbf{S} \\
\mathbf{P} \\
\mathbf{S} \\
\mathbf{P} \\
\mathbf{S} \\
\mathbf{P} \\
\mathbf{S}\end{array}$ & $\begin{array}{l}\text { Heterorhahditis } \\
\text { bacteriophora } \\
\text { H. bacteriophora } \\
\text { H. heliothidis } \\
\text { H. heliothidis } \\
\text { H. heliothidis } \\
\text { H. heliothidis } \\
\text { Heterorhabditis sp. } \\
\text { Heterorhabditis sp. } \\
\text { Heterorhabditis sp. } \\
\text { Heterorhabditis sp. }\end{array}$ & $\begin{array}{l}\text { Australia } \\
\text { Australia } \\
\text { Australia } \\
\text { Australia } \\
\text { USA (N. Carolina) } \\
\text { USA (N. Carolina) } \\
\text { Netherlands } \\
\text { Netherlands } \\
\text { USA (California) } \\
\text { USA (California) }\end{array}$ & $\begin{array}{l}2 \\
2 \\
2 \\
2 \\
6 \\
6 \\
7 \\
7 \\
8 \\
8\end{array}$ \\
\hline \multicolumn{6}{|c|}{$\begin{array}{l}\text { - P, primary; S, secondary. } \\
\text { † Sources: 1, John All, Department of Entomology, University of Georgia, Athens, Ga., USA; 2, Ray Akhurst. } \\
\text { Division of Entomology, CSIRO, Hobart, Tasmania, Australia; 3, Randy Gaugler, Department of Entomology } \\
\text { and Economic Zoology, Cook College, Rutgers University, New Brunswick, NJ, USA:4, Kathrine Deseo, Centro } \\
\text { de Fitofarmacia, University of Bologna, Bologna, Italy; 5, James Lindegren, Stored Product Insect Research } \\
\text { Laboratory, Fresno, Calif., USA;6. Wayne Brooks, Department of Entomology, North Carolina State University, } \\
\text { Raleigh, NC, USA: 7, W. R. Simons, Agriculture College, Leeuwarden/Laboratory of Nematology, Agricultural } \\
\text { University of Wageningen. The Netherlands: 8, William Bowen, Department of Entomology, University of } \\
\text { California, Riverside. Calif., USA. }\end{array}$} \\
\hline
\end{tabular}

Table 2. Characteristics of Xenorhabdus isolated from Heterorhabditis collected in the Netherlands and Victorville, USA

Characteristic

No. of isolates

Cell morphology

Motility

Gram stain

Colony diameter $(\mathrm{mm})$

Pigmentation in:

nutrient agar

MacConkey agar

Catalase

Bioluminescence

Antibiotic activity against isolates:

A25, A25

T319/1, T319/2

G6

SK $3 / 1$, SK $3 / 2$

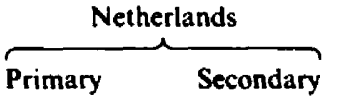

$\begin{array}{cc}\text { Primary } & \text { Secondary } \\ 8 & 8 \\ \text { rod } & \text { rod } \\ + & + \\ - & - \\ 2 \cdot 0-2 \cdot 5 & 2 \cdot 5-3 \cdot 0 \\ \text { orange } & \begin{array}{c}\text { orange } \\ \text { red }\end{array} \\ - & - \\ + & + \\ + & + \\ + & + \\ + & + \\ + & +\end{array}$

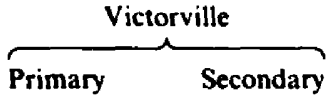

$\begin{array}{cc}8 & 9 \\ \operatorname{rod} & \text { rod } \\ + & + \\ 3.0-3.5 & 3.5-4.0\end{array}$

$\begin{array}{cc}\begin{array}{c}\text { orange } \\ \text { red } \\ -\end{array} & \begin{array}{c}\text { buff } \\ \text { pink }\end{array} \\ + & - \\ + & + \\ + & + \\ + & + \\ + & +\end{array}$




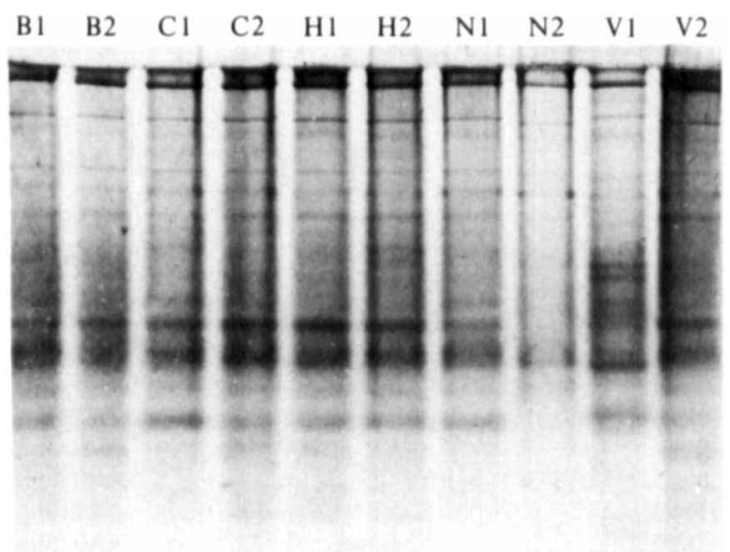

Fig. 1. Protein profiles of Xenorhabdus luminescens. See Table 1 for abbreviations of bacteria.

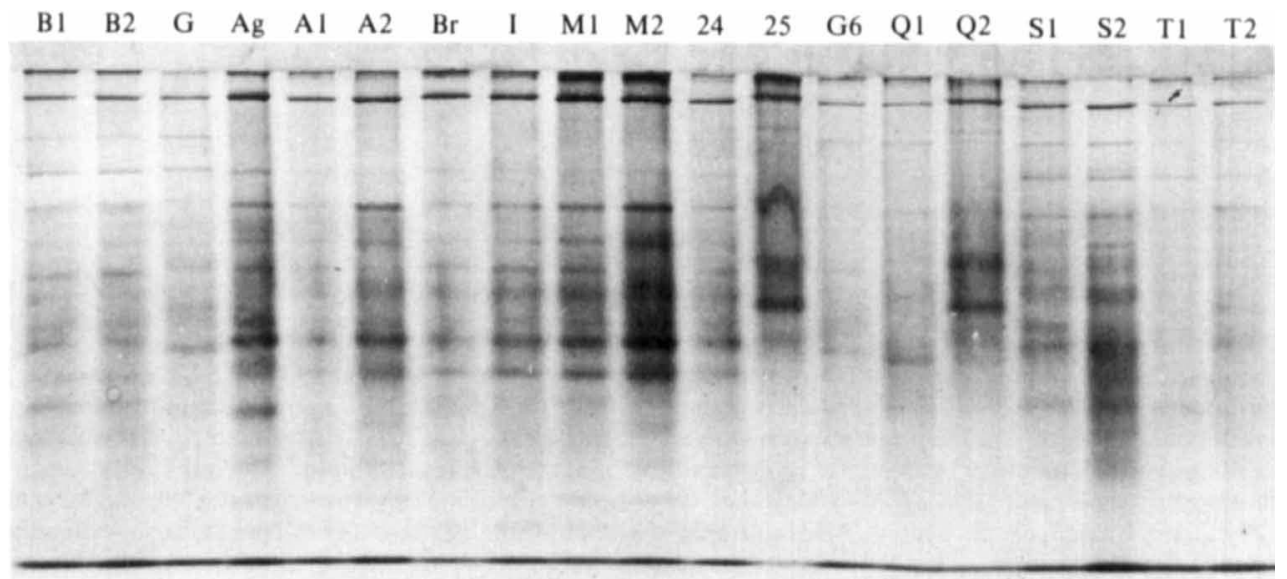

Fig. 2. Protein profiles of Xenorhabdus nematophilus. See Table 1 for abbreviations of bacteria. B, Bib; G, Glas; Ag, Agro; A, All; Br, Bret; I, Ital; M, Mex; Q. Q58; S, SK3; T, T319.

circular with an almost smooth margin, green with a large green-brown centre, and with a clear zone in the agar surrounding the colonies. The secondary form, however, was different from those previously described. Colonies were convex, circular with an irregular margin, brick red throughout, and imparted a red colour to the NBT agar.

Electrophoretic separation of $X$. nematophilus and $X$. luminescens is shown in Figs 1 and 2. Protein profiles were virtually identical for primary and secondary forms and within most subspecies of $\boldsymbol{X}$. nematophilus from different geographical locations. Further, the different subspecies were electrophoretically distinct. Very little qualitative difference was observed between the protein profiles of $X$. nematophilus subsp. nematophilus and $X$. nematophilus subsp. bovienii. The former isolates had an additional band in the low molecular weight proteins as compared to the latter (isolates Bib and T319). The two $X$. nematophilus subsp. poinarii isolates were notably different in protein mobility. The group IV isolates were very similar in profile to that of $X$. nematophilus subsp. bovienii isolates SK 3/1 and SK3/2. 


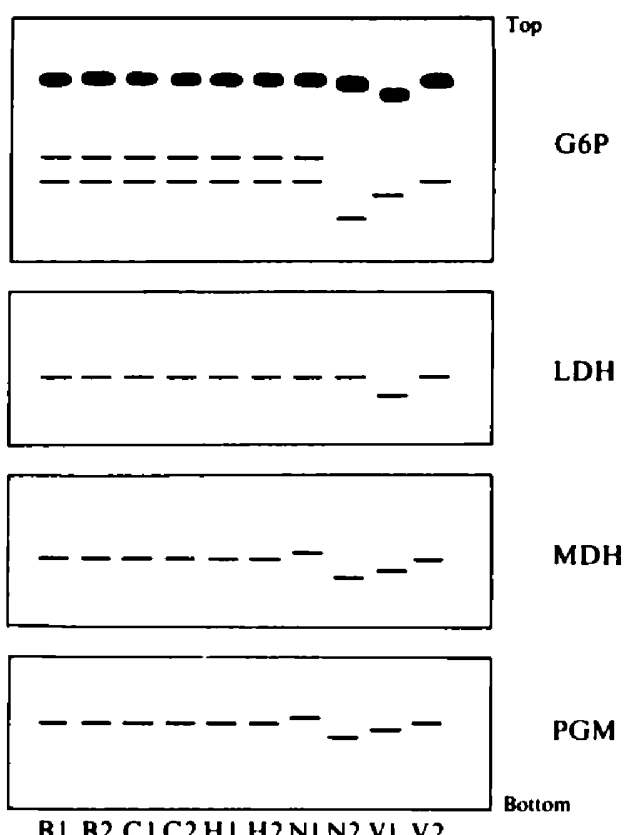

Fig. 3. Isoenzyme stains of Xenorhabdus luminescens. See Table 1 for abbreviations of bacteria. G6P, glucose-6-phosphate dehydrogenase; $\mathrm{LDH}$, lactate dehydrogenase; $\mathrm{MDH}$, malate dehydrogenase; PGM, phosphoglucomutase.

The protein profiles of the primary and secondary forms of the two $H$. heliothidis isolates and the one $\boldsymbol{H}$. bacteriophora isolate of $\boldsymbol{X}$. luminescens were identical. However, the profile of the Netherlands and Victorville isolates differed in their primary and secondary forms from each other and from the other isolates. Further, the primary and secondary forms of the Victorville isolate differed from each other. Thus the primary and secondary forms of the Netherlands and Victorville isolates gave the appearance of being two separate strains.

Results from isoenzymic reactions substantiated the differences observed in the protein profiles (Figs 3 and 4). All isolates of $X$. luminescens, except for the secondary form of Netherlands and the primary form of Victorville, had identical mobility for all isoenzymes. The enzyme bands of primary Victorville forms consistently migrated faster than those of secondary Netherlands forms, which, in turn, migrated faster than enzyme bands of other isolates. Three isoenzyme reactions (MDH, LDH and PGM) revealed only one band and one isoenzyme reaction (G6P) had two or three bands.

The $X$. nematophilus isolates showed more isoenzymic variability than the $X$. luminescens isolates. Geographically distinct isolates had similar banding patterns except for isolate SK 3, which differed from other $X$. nematophilus subsp. bovienii isolates (Bib and T319) in G6P and MDH reactions, and G6 and Glas which differed in G6P, LDH and MDH reactions. Group IV (Q58) was similar to $X$. nematophilus subsp. bovienii in 6PG reactions and to $X$. nematophilus subsp. nematophilus in LDH reaction. The MDH pattern of $X$. nematophilus subsp. nematophilus revealed numerous bands whereas other species had only one or two bands. All $X$. nematophilus extracts were prepared at the same time and under the same conditions and it seems unlikely therefore that these multiple MDH bands represent breakdown products. Alternatively, the MDH proteins of $X$. nematophilus subsp. nematophilus may be very heat labile and, despite cooling of the electrophoretic system, heating may have caused some denaturation of protein. 


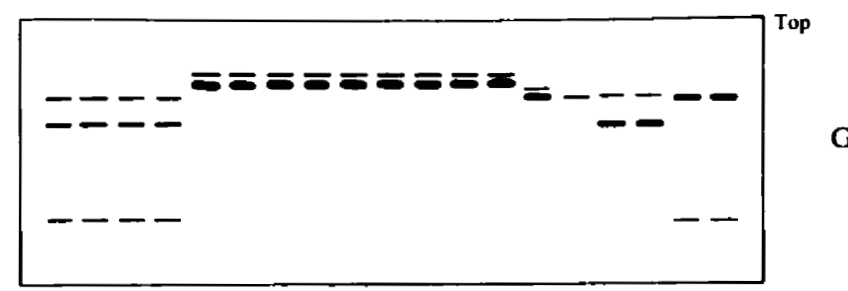

G6P

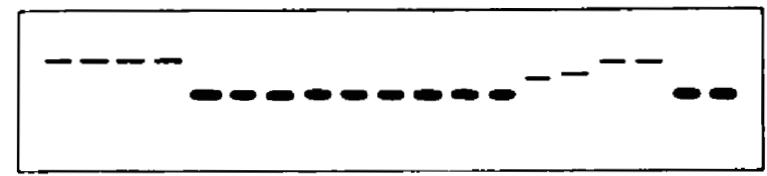

LDH

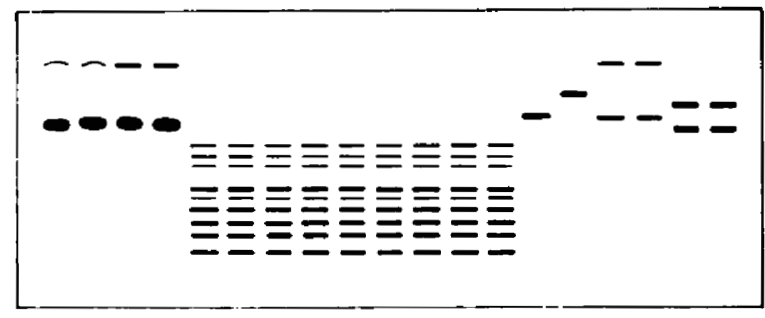

MDH

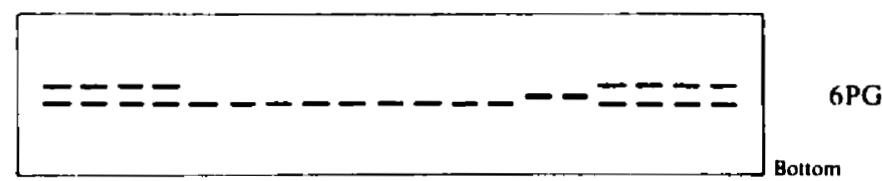

TI T2 BI B2 2425 A1 A2 Ag Br I M1M2G6G S1 S2Q1Q2

Fig. 4. Isoenzyme stains of Xenorhahdus nematophilus. See Table I for abbreviations of bacteria. G6P, glucose-6-phosphate dehydrogenase; LDH, lactate dehydrogenase: $M D H$, malate dehydrogenase: 6PG, 6-phosphogluconate dehydrogenase.

\section{DISCUSSION}

Electrophoretic techniques for identification and classification are widely utilized and are particularly useful for organisms that are difficult to distinguish by other means. Electrophoretic differences between bacterial strains can serve as a powerful tool for separation of species and subspecies because the same set of proteins is always produced by bacteria grown in standardized conditions (Kersters \& De Ley, 1980). However, with physiological and biochemical tests, the results may differ for identical species because of subjective interpretation of test results. These differences in interpretation can be overcome by electrophoretic techniques. Hence, isolates collected world-wide can be electrophoretically compared to one another for absolute identification of species (subspecies or strain) status.

Protein profiles of subspecies within the $X$. nematophilus group were similar but easily distinguished from one another and essentially substantiated previous subspecific designations. Subspecific isolates from the USA, Europe and Australia had virtually identical protein profiles in both the primary and secondary forms. Although isolate G6 differed from isolate Glas, this was probably due to the occurrence of two secondary forms of $X$. nematophilus subsp. poinarii (Akhurst, 1982). One can only speculate as to why $S$. glaseri has two secondary forms of bacteria. The profile of isolate SK3 bears a stronger resemblance to that of isolate Q58 than to the other two isolates of $X$. nematophilus subsp. bovienii (Bib and T319).

Protein profiles of isolates of $X$. luminescens from $H$. bacteriophora and $H$. heliothidis were identical, but differed from both Victorville and Netherlands isolates. The primary and secondary profiles of Victorville isolates differed from each other. This evidence suggests that there may be at least two subspecies of $X$. luminescens. 
Since proteins with different primary structure may produce identical electrophoretic profiles, it is important to corroborate similarities by other methods, such as staining for specific enzymes or isoenzymes, as we have done. Coyne (1982) demonstrated that isoenzymes with apparently identical mobilities can be separated by changing electrophoretic conditions ( $\mathrm{pH}$ of the separating gel and gel concentration), thus revealing cryptic protein variations. Although we expected no differences in isoenzyme profiles from isolates of the same subspecies, when we did look for cryptic differences in two enzymic reactions, we found the isoenzyme patterns to be unchanged.

Isoenzymic reactions may be used as further phenotypic evidence to confirm differences between subspecies, as seen when gels were stained for total proteins. The MDH, LDH and 6PG results revealed isolate SK 3 to be close but not identical to the other $X$. nematophilus subsp. bovienii isolates (Bib and T319). However, the G6P results clearly separated the SK 3 isolates. The Q58 isolates appear to be a different subspecies as overall isoenzymic reactions were not similar to any one subspecies.

Isoenzyme patterns of $X$. luminescens isolates reveal further differences between primary and secondary forms of Netherlands and Victorville isolates. The primary form of Netherlands and the secondary form of Victorville were always consistent with the other $X$. luminescens isolates, although the protein profile of secondary Victorville was clearly different from the other profiles. The phenotypic evidence from the protein profiles and isoenzyme patterns, taken with the gross morphology of the colonies of the Netherlands and Victorville isolates, suggests that these bacteria do not entirely conform to the description of $X$. luminescens. The cumulative evidence suggests several possibilities: that $X$. luminescens is composed of more than one primary or secondary form (analagous to the situation with $X$. nematophilus subsp. poinarii), that it is comprised of more than one subspecies, or that there is more than one species of Xenorhabdus associated with heterorhabditid nematodes.

We thank Dr Philip S. Ward, Department of Entomology, University of California, Davis, for critical review of this manuscript. Special thanks are extended to Dr Ray Akhurst for initial guidance and for supplying bacteria used in this study.

\section{REFERENCES}

AKhURst, R. J. (1980). Morphological and functional dimorphism in Xenorhabdus spp., bacteria symbiotically associated with the insect pathogenic nematodes Neoaplectana and Heterorhahditis. Journal of General Microbiolog. 121, 303309.

AKHURST, R. J. (1982). Antibiotic activity of Xenorhabdus spp., bacteria symbiotically associated with insect pathogenic nematodes of the families Heterorhabditidae and Steinernematidae. Journal of General Microbiology 128, 3061-3065.

AkhURSt, R. J. (1983a). Taxonomic study of Xenorhahdus, a genus of bacteria symbiotically associated with insect pathogenic nematodes. International Journal of Systematic Bacteriolog. 33, 38-45.

AKhURST, R. J. (1983b) Neoaplectana species: specificity of association with bacteria of the genus Xenorhabdus Experimental Parasilology 55, 258-263.

BOWEN, W. R. (1982). New discovery. Unitersity of California. Riterside Extension Entomology Specialist Letter, no. 2 June 1982.

Bradford, M. M. (1976). A rapid and sensitive method of the quantitation of microgram quantities of protein utilizing the principle of protein-dye binding. Analytical Biochemistry 72, 248-254.
CoYNe, J. A. (1982). Gel electrophoresis and cryptic protein variation. In /sozymes: Current Topics in Biological and Medical Research. vol. 6, pp. I-32. Edited by M. C. Raktazzi, J. S. Scandalios \& G. S. Whitt. New York: A. R. Liss.

Davis, B. J. (1964). Disc electrophoresis. II. Method and application to human serum proteins. Annals of the Nen York Academy of Sciences 121, 404-427.

Kersters, K. \& De LeY, J. (1980). Classification and identification of bacteria by electrophoresis of their proteins. In Microbiological Classification and Identification. pp. 273-297. Edited by M. Goodfellow \& R. G. Board. New York: Academic Press.

Simons, W. R. (1981). Biological control of Otiorrhynchus sulcatus with heterorhabditid nematodes in the glasshouse. Netherlands Journal of Plant Patholog.' 87. $149-158$.

Thomas, G. M. \& Poinar, G. O. (1979). Xenohabdus gen. nov., a genus of entomopathogenic, nematophilic bacteria of the family Enterobacteriaceae. International Journal of Systematic Bacteriolog. 29. $352-360$. 